\title{
Reviewers for Volume 35
}

Mike Arons

Lisa Cosgrove

Constance T. Fischer

Harris Friedman

George Howard

Belinda Khong

Bruce Levi

Heidi Levitt

Arthur Lyons

Bertha Mook

Christopher Mruk

David Rennie

Kathleen Wall

Elli Weiner

Frederick Wertz 